\title{
Costs and benefits to European shipping of ballast-water and hull-fouling treatment: impacts of native and non- indigenous species
}

Jose A. Fernandes ${ }^{1 *}$, Lionel Santos, Thomas Vance ${ }^{2}$, Tim Fileman ${ }^{2}$,

David Smith ${ }^{1}$, John D.D. Bishop ${ }^{3}$, Frédérique Viard ${ }^{4,5}$, Ana M. Queirós $^{1}$, Gorka Merino ${ }^{6}$, Erik Buisman ${ }^{7}$ and Melanie C. Austen ${ }^{1}$

${ }^{1}$ Plymouth Marine Laboratory, PL1 3DH, Plymouth, UK

${ }^{2}$ PML Applications, PL1 3DH, Plymouth, UK

${ }^{3}$ Marine Biological Association of the United Kingdom, Citadel Hill, PL1 2PB Plymouth, UK

${ }^{4}$ Sorbonne Universités, UPMC Univ Paris 06, UMR 7144, Station Biologique de Roscoff, 29680

Roscoff, France.

${ }^{5}$ CNRS, UMR 7144, Divco team, Station Biologique de Roscoff, 29680 Roscoff, France.

${ }^{6}$ AZTI-Tecnalia, Herrera Kaia, Portualdea, z/g, Pasaia (Gipuzkoa), 20110, Spain

${ }^{7}$ LEI-Wageningen UR, Alexanderveld 5, 2585DB, 'S Gravenhage, Netherlands.

\section{KEYWORDS}

Non-indigenous species, native, biofouling, ballast water, economic impact, maritime, shipping, mitigation measures 


\section{ABSTRACT}

Maritime transport and shipping are impacted negatively by biofouling, which can result in increased fuel consumption. Thus, costs for fouling reduction can be considered an investment to reduce fuel consumption. Anti-fouling measures also reduce the rate of introduction of non-indigenous species (NIS). Further mitigation measures to reduce the transport of NIS within ballast water and sediments impose additional costs. We estimate that the operational cost of NIS mitigation measures may represent between $1.6 \%$ and $4 \%$ of the annual operational cost for a ship operating on European seas, with the higher proportional costs in small ships. However, fouling by NIS may affect fuel consumption more than fouling by native species due to differences in species' life-history traits and their resistance to antifouling coatings and pollution. Therefore, it is possible that the cost of NIS mitigation measures could be smaller than the cost from higher fuel consumption arising from fouling by NIS.

\section{GRAPHICAL ABSTRACT}

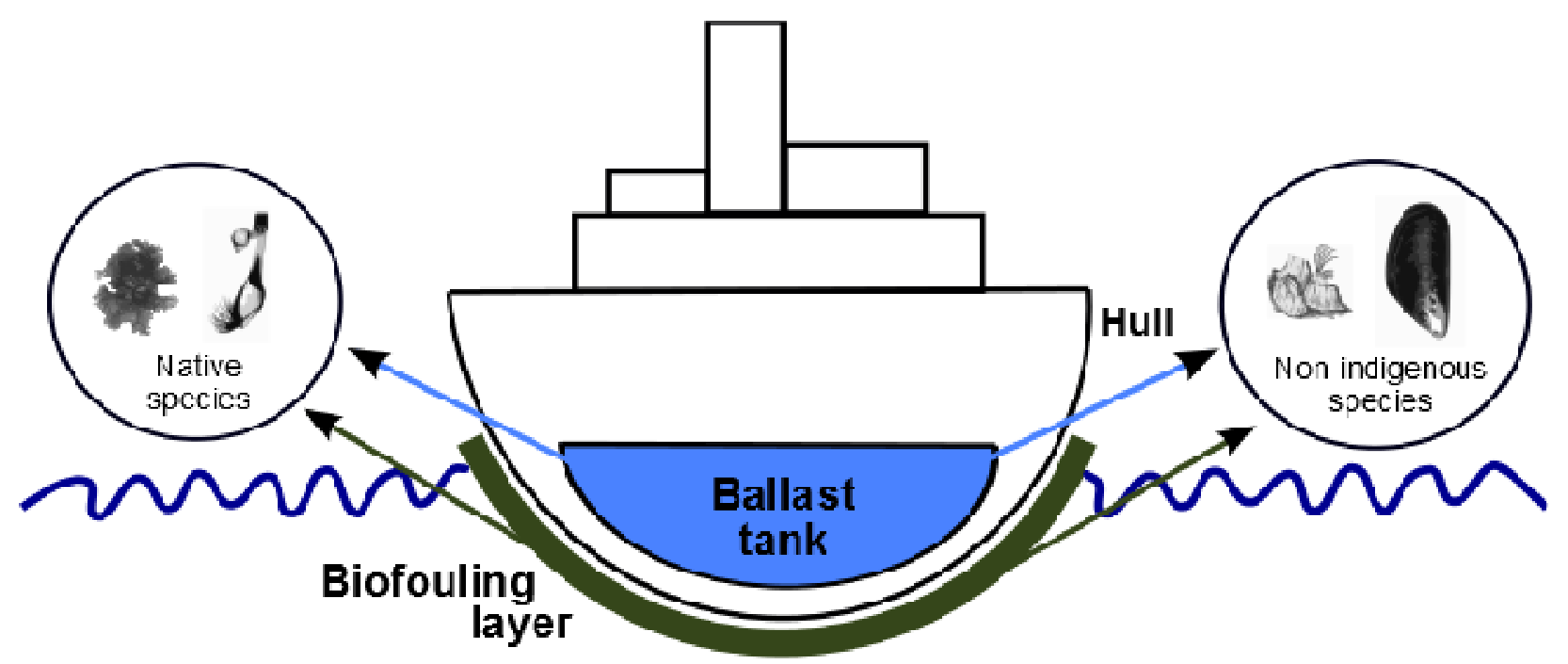




\section{INTRODUCTION}

Fouling on hulls and ballast water in ships are two of the most important vectors for the introduction of non-indigenous species (NIS) into aquatic ecosystems (Reise et al., 1999; Bax et al., 2003; Minchin et al., 2003; Olenin et al., 2010). As many as 990 different living taxa have been observed in ballasts in Europe (Gollasch et al., 2002), including microbes harmful to human health such as Vibrio cholerae (McCarthy et al., 1994) and Escherichia coli (Schernewski et al., 2014). These routes can act as vectors for human-mediated introduction of species to new regions and the expansion of species' native ranges, depending on other factors such as climate change (Rahel and Olden, 2008; Hulme, 2009; Simkanin et al., 2009; Vilà et al., 2010). Current projections estimate that climate change alone may increase the rate of NIS introductions into European waters by 15 to $30 \%$ by mid-century (Cheung et al., 2009; Pereira et al., 2010, Fernandes et al. 2013). Potential synergies between shipping vectors and other human-driven effects like climate change can thus lead to substantial changes in the distribution and productivity of both native species and NIS. These can cause important changes to the structure and functioning of marine ecosystems, with social and economic consequences (Pimentel et al., 2005; Rilov and Crooks, 2009; Perrings, 2010; Vilà et al., 2011).

These impacts have been recognized by the International Marine Organization (IMO) and local agencies, which have introduced management guidelines for biofouling (Roberts and Tsamenyi, 2008; IMO, 2011; US Coast Guard, 2012; Scriven et al., 2015). The IMO also strives to implement legislation in the Ballast Water Management Convention; Section D of the Convention Regulation considers the installation of IMO- type-approved onboard ballast water treatment systems (BWTS) to meet the D-2 discharge standard - a quality standard insuring against the presence of living organisms in discharged waters. The recently introduced US Coast Guard and US EPA regulations establish similar standards (US Coast Guard, 2012; US EPA, 2013). As of 17 October 2014, after 14 years of negotiations, 43 states 
had ratified the convention, representing $32.5 \%$ of world merchant shipping tonnage (IMO; http://www.imo.org/About/Conventions/StatusOfConventions), still below the tonnage required to enable the convention to enter into force (35\%). However, it is approaching the threshold for enforcement (Liu et al., 2014). The cost of these mitigating strategies to the shipping industry is largely unquantified. This study aimed to bridge this gap.

Anti-fouling and new ballast regulations are seen as costs by the shipping industry. However NIS, which have the potential to become invasive, could also negatively affect the industry through biofouling of hulls, increasing fuel consumption. Organism assemblages attached to the underwater surfaces of ships (biofouling) significantly reduce propulsion efficiency through increased drag, leading to increased fuel consumption and emissions (Pyefinch, 1954). A significant portion of this fuel is used to overcome the frictional resistance between the ship's hull and the water (Swain et al., 2007), and this can be as high as $40-80 \%$ of the total fuel consumption of a given ship. Antifouling paints and coatings that help to control biofouling of ships hulls have thus been in use for many decades (Redfield et al., 1952). In parallel, most of the world's shipping fleets have decreased their average speeds by up to $56 \%$ to reduce fuel consumption (Smith et al., 2013), driven by the onset of the Western financial crisis and a decrease in global trade in recent years (Asariotis et al., 2012). Regardless, the potential financial gain associated with a reduction of biofouling and of the associated fuel expenditure in shipping remains unquantified. It is therefore unclear whether mitigation measures aimed at reducing transport of organisms could generate long-term financial benefits to the shipping industry by reduction of drag and hence of fuel consumption.

In this work, we examine the cost of NIS mitigation measures and potential savings from those measures due to the additional cost of hull fouling caused by NIS relative to native species in terms of fuel consumption. This difference is due to differences in their respective biological traits. Antifouling is directed at both native and non-indigenous species and costs 
are offset by fuel savings. But antifouling will also reduce the spread of NIS. Ballast water treatment is primarily directed at reducing/preventing the spread of NIS, with no immediate compensatory fuel saving. However, reducing the spread of NIS may lead to a reduction in future fuel costs imposed by biofouling, if fouling NIS that have been spread in ballast (e.g. as larvae) subsequently exert heavier fouling costs than native species. Therefore we estimate the increased costs of fuel consumption between NIS and native species induced fuel consumption. But, we also calculate the potential savings if NIS species have a higher impact on hull bio-fouling and, therefore, fuel consumption considering that ballast water treatment systems will reduce NIS spread. 


\section{MATERIALS AND METHODS}

We firstly collate a list of species that have been observed to be the most problematic for the shipping industry in European waters in terms of their prevalence on ships hulls, even when anti-fouling measures are in place. Then, we investigate possible ecological differences between the native species and NIS in these communities, which may have a bearing on fuel consumption. The effect of those factors is then contrasted with the cost to the shipping industry of NIS mitigation measures (anti-fouling and ballast waters) under current maritime regulation trends. We break down these costs in relation to the different types of ship to investigate impacts on the consumer, because different types of ship are associated with the transport of different types of goods.

\section{Calculation of impact on fuel consumption of native and non-indigenous}

\section{species (NIS)}

A list of algal and animal species found in external ship fouling and in ballast waters in Europe was compiled based on publications that comprehensively studied these communities (Reise et al., 1999; Gollasch et al., 2002; Minchin et al., 2003; Olenin et al., 2010; Leppäkoski et al., 2000; Paavola et al., 2005; Mineur et al., 2007; Sarà et al., 2007), together with a selection of species from the AquaNIS database on aquatic NIS (http://www.corpi.ku.lt/databases/index.php/aquanis/). This list of 302 species was reviewed by a biofouling expert (T. V.) who selected a subset of 59 species considered to be most problematic for increasing the fuel consumption of ships through biofouling due to their prevalence on hulls, resistance to anti-fouling measures, frictional resistance and growth (henceforth, "the most problematic"; Appendix I). The species list was then revised by an external, independent expert in another European country. The final list included barnacles (15), tunicates (14), bryozoans (13), tube worms (4), molluscs (4), sponges (3), algae (3) and 
cnidarians (3). Once this list was established, four categories of ecological traits were considered based on the reasons for their impact on fuel consumption: 1) fast growth or high reproduction rate; 2) known resistance to pollutants or anti-fouling measures; 3) morphological shape or size that produces frictional resistance; or 4) high abundance/biomass or prevalence. Information regarding these traits, for the species list, was sought from public datasets, specifically: SeaLifeBase (http://www.sealifebase.org); BIOTIC (http://www.marlin.ac.uk/biotic); WoRMS (http://www.marinespecies.org); MarBEF (http://www.marbef.org/data/aphia.php?p=match) and Natural England database (http://www.naturalengland.org.uk/ourwork/conservation/biodiversity/threats/nonnativeaudit. $\underline{\operatorname{aspx}}$ ). These databases were further used to determine which of the species listed are present in each of the three specific European regional seas of interest to this study (Western Mediterranean, Baltic and North Sea) and whether each species is considered native or NIS in each area. Given data availability, a set of factors associated with these traits were selected covering all the trait categories.

The factors considered were: the von Bertalanffy growth parameters (Linf, theoretical maximum size of an organism; $K$, growth rate; and, $\varnothing$, mean size; from public and private databases) because rapid growth leads to greater fouling potential; length-weight relationship parameters (referred to as a and $b$; from public databases) for the same reasons; resistance to contamination (from literature) indicating greater ability to withstand anti-fouling measures (Karatayev et al., 2009; Crooks et al., 2011); bending capacity (from public databases) indicating greater ability to persist when underway instead of breaking and falling off; salinity range, enabling resistance to possible hydrological changes during transport; growth pattern (from biological databases and J. B. expert knowledge), considering colonial growth patterns leading to greater fouling potential than solitary patterns; hydrodynamic resistance (T. V. expert knowledge), proportional to impact on drag; and ability to colonize artificial substrates (presence on settlement panels from unpublished data sets), also associated with 
greater fouling potential. In the case of hydrological resistance, the species were ranked between 1 and 3, where thin and flexible morphological forms such as filamentous algae would be considered to have a resistance of 1 and an organism with a large, architecturally complex and inflexible form such as oysters were classified as having a resistance of 3 . As an exception, the trait value for "Growth pattern", representing whether the species multiplies vegetatively into a group of associated modular units (e.g. zooids or polyps in animal taxa) following settlement (= colonial), or grows as a single organism from the settling propagule (= non-colonial), could be specified in all instances, because expert knowledge was used when published data were not available (J.B.). For the qualitative growth pattern, a value was assigned to each category since a colonial pattern can lead to more successful lateral spreading (Floerl et al., 2004): two for colonial; and one for non-colonial (as defined in the BIOTIC database).

Direct species-by-species comparison was not possible since no species had data for all the traits and the percentage of species that had data for a given trait ranged between $13.6 \%$ and $59.2 \%$. For each of the traits, an indicator (hereafter named 'factor index') was calculated to compare the average score value found for NIS in relation to native species. This was calculated by averaging the values for each trait in NIS and dividing it by the average from native species present in each sea. A value larger than one thereby indicated that NIS would have a higher rank in that particular trait. Then, the factor indices were summarized for the three regional seas using a geometric mean. A geometric mean is appropriate for considering different interrelated factors when each item has multiple properties that have different numeric ranges (Mitchell, 2004; Galton et al., 1879; Brown and Woods, 2012). We estimated uncertainty in the data by calculating the standard deviation of the values using a "leaving one out schema" (LOO; Mosteller and Tukey, 1968; Fernandes et al., 2010; Rodríguez et al., 2013). In a LOO scheme, we recalculate the values multiple times leaving one species out each time and reporting the standard deviation of the calculated values in order to quantify 
the effect of data sparseness in our estimations. This estimate showed that the variability of the results is smaller than the range of the effects observed between NIS and native species indices, supporting our hypothesis. A paired t-test (Nadeau and Bengio, 2003; Fernandes et al., 2009) also showed that most of the NIS index values are higher than those for natives at a statistically significant level $(\mathrm{p}>0.01)$.

In order to account for the prevalence of some species over others, settlement panels deployed in several marinas were used. Vertical $15 \times 15 \mathrm{~cm}$ panels of polypropylene were deployed at $1.5 \mathrm{~m}$ depth for 1 year at 6 marinas in Brittany and 7 marinas in Devon and Cornwall, and retrieved in spring of 2011, 2012 and 2013 (from February to early April). For each year and marina, sets of panels were placed at two locations classified as 'inner' and 'outer', being far from and close to the entrance to the open sea, respectively (later referred as "Panels coverage Outer" and "Panels coverage Inner"). Each side of the panel was scored at 100 points in a grid pattern where the taxa (one or more) present under each point was/were noted.

\section{Calculation of costs of NIS mitigation measures to the shipping industry}

The installation of ballast water treatment systems (BWTS) represents an additional cost for the shipping industry. Anti-fouling measures (codified in the IMO Control and Management of Ship's Biofouling Guidelines) not only reduce NIS spread, but also reduce fuel consumption. Both costs (BWS and anti-fouling) were calculated based on available literature and surveys to shipping companies. These costs were here divided into operating and capital costs. The operating costs refer to the annual cost of consumables (e.g. fuel or chemicals) and the annual capital cost refers to investments made one year (e.g. for machinery purchase and installation) which are amortized over several years (the shipping industry normally determines annual capital costs based on a 25-year amortization period). 
To reduce the complexity of calculating the cost of mitigation measures across a diverse range of vessels, we have grouped ships (Fig. 1) with similar characteristics in terms of BWTS and antifouling measures based on published work (King et al., 2012) and informal interviews undertaken with representatives of the shipping industry and with shipping experts. Six of the groups (referred to as "categories" in the following text), 2 in each ballast water volume classification $\left(<1500,1500\right.$ to $\left.5000,>5000 \mathrm{~m}^{3}\right)$, account for $93 \%$ of the world fleet requiring BWTS, the remaining 7\% representing a mix of characteristics that could not be fitted in this categorization. The IMO uses these ballast water volume classifications in its Ballast Water Management Convention. However, in terms of cost, the pumping capacity of a ship (i.e. the rate at which ballast water is taken on board or discharged) is a more important factor since higher pumping rates $\left(\mathrm{m}^{3} / \mathrm{h}\right.$ ) demand larger BWTS (as a unit or as replicate systems) to give the required treatment-rated capacity.

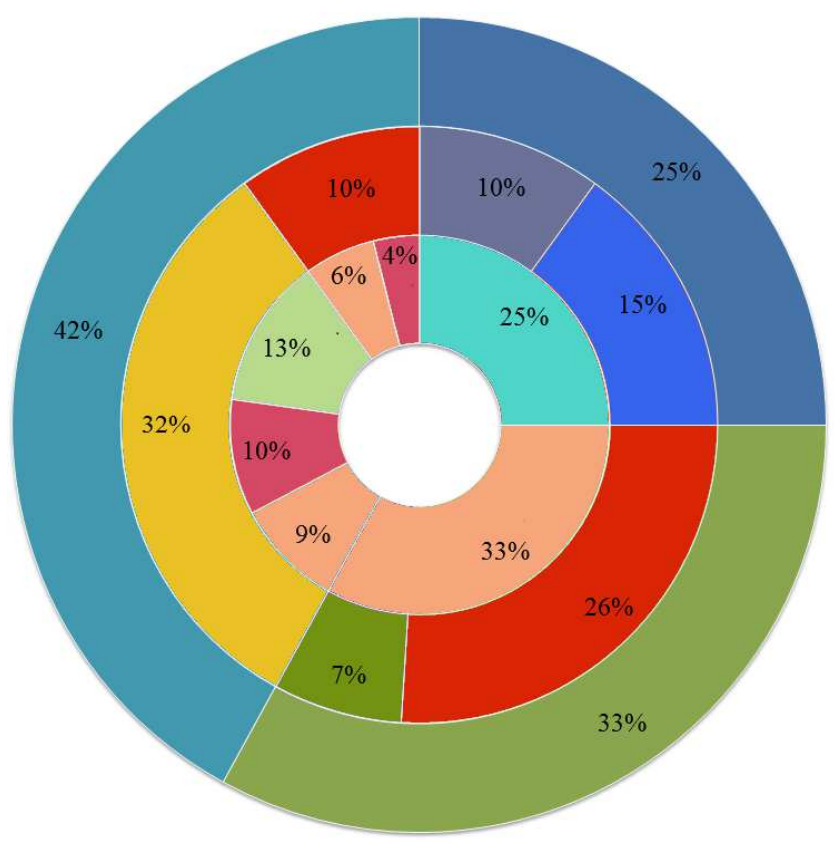

\section{OUTER RING}

Ballast waters system $<1500 \mathrm{~m}^{3}$

Ballast waters system $1500-5000 \mathrm{~m}^{3}$

Ballast waters system $>5000 \mathrm{~m}^{3}$

MIDDLE RING

Passenger ships, cruisers, cargo (Ro-Ro)

Fishing vessels and OSVs

General cargo and container ships

Refrigerated, livestock, vehicle, Ro-Ro cargo ships

Bulk carrier and tankers (oil, chemical, and other)

\section{INNER RING}

DWT $<10000$ tons

DWT $<30000$ tons

DWT $<70000$ tons

DWT $>70000$ tons

FIGURE 1. Distribution of world shipping according to three criteria; ballast water volume, type of vessel and Dead Weight Tonnage (DWT) based on published data (King et al., 2012). These categories account for $93 \%$ of the world fleet that use ballast water. Inner rings represent subcategories of outer ring ballast water volume 
classifications. As an example, all ships with ballast waters volume of $<1500 \mathrm{~m}^{3}$ are passenger and fishing vessels of $<10000$ tonnes.

Recent literature reviews have identified the expected costs of the new BWTS (Berntzen, 2011; Yoon, 2011; King et al., 2012) for each of these different types of shipping groups as well as estimating the proportion of their annual costs that this would represent (Asariotis et al., 2012; US Department of Transportation Maritime Administration, 2011). In addition, a survey of key shipping companies for this study $(n=6)$ was designed and conducted to provide specific case studies that could be compared with the published costs (Appendix II). 


\section{RESULTS}

The results of comparing the impact of NIS and native species on fuel consumption are presented. Then we look at the cost of mitigation measures and discuss the relationship between these two costs.

\section{Comparison of potential impact of NIS and native species on fuel consumption.}

An average Factor Index above 1 in each of the three regions (Table 1) suggested that NIS can have a higher impact in aspects of biofouling that can affect fuel consumption than native species (as described here) in the three European seas we studied. In this work, this hypothesis was formulated on the basis that biofouling is recognized to be among the most important vectors of species introduction (Reise et al., 1999; Minchin et al., 2003; Olenin et al., 2010; Sylvester et al., 2011). NIS arriving through this vector have thus been able to survive the antifouling measures used by ships as well as natural ecological barriers to their movement such as temperature, salinity and hydrodynamic factors; as a result, they differ from species resident in their native range. Growth rate and length-weight relationship were found to have average index values higher than 1. In contrast, the native species we considered were found to have a higher average for salinity tolerance in all the areas. This could be an artifact of the limited salinity tolerance data for the species in our "problematic species' list since there is data for only $9.1 \%$ of NIS species in contrast to $36.4 \%$ of natives.

The index for prevalence (panel coverage) related to 13 marinas on the UK and French coasts of in the English Channel, sampled three times. The sites are predominantly recreational, not near industry, and not generally subject to strong salinity fluctuations. There was substantial variation between these 13 sites. On the 'inner' panels, from the inner marina areas, the prevalence of NIS was higher than natives. In contrast, on the 'outer' panels placed in the limits of the marina and likely to be more influenced by currents, the prevalence of natives was higher than NIS. Those results suggest that NIS species in our datasets favoured 
sheltered areas with relatively low water movement except in the West Mediterranean Sea where the opposite pattern is observed. Bending also shows consistent patterns for the North Sea and Baltic with higher bending capacity by NIS, but an opposite behaviour in the Mediterranean Sea. Growth pattern shows quite a consistent pattern across different seas with a value of less than 1 , except in the Baltic Sea with a value of approximately 1 . The evidence suggests that on average a smaller proportion of NIS is colonial.

Results of the aggregation of species information by regional sea (summarised in Table 1) suggests that NIS exhibit one or more biological traits that indicate that they can affect fuel consumption caused by hull biofouling to a greater extent than native species. However, these indices have to be considered with caution, since they are based on species averages calculated with limited data availability. It was not possible to directly compare life-history data factor by factor for each taxonomically comparable pair of native species and NIS since data are not available for many of the species or factors. Hence, averaging of the factors was carried out over groups of species for which data were found. This aspect may have caused some bias in our results given that it is more likely that data are available for NIS that have been found to be problematic: i.e. those that are more successful in the introduction process, and thus likely to score highest in our indices (Colautti and Macisaac, 2004). The vast majority of non-indigenous species are expected to have lower success, remaining unidentified for long periods, and these are likely to be missing from our analysis. Regardless, this study is a first attempt to bring these data together to extrapolate possible consequences to the shipping industry, and may be improved with a wider evidence base. In addition, some of the indices, such as resistance to organic pollutants (Karatayev et al., 2009) and resistance to copper in particular (Crooks et al., 2011), are generalizations from single studies due to the paucity of data. However, these still provide evidence that supports our hypothesis that NIS can impact fuel consumption more than native species in fouling communities. 


\begin{tabular}{|c|c|c|c|c|c|}
\hline Area & Index category & Parameters & Native & NIS & Factor index \\
\hline Baltic Sea & $\begin{array}{l}\text { Prevalence } \\
\text { Resistance } \\
\text { Overall index mean }\end{array}$ & $\begin{array}{l}\text { Growth }\left(\mathrm{L}_{\infty}\right) \\
\text { Growth }(\mathrm{K}) \\
\text { Growth }(\varnothing) \\
\text { Length-Weight (a) } \\
\text { Length-Weight (b) } \\
\text { Bending (degrees) } \\
\text { Salinity (psu) } \\
\text { Growth pattern } \\
\text { Hydrodynamic resistance } \\
\text { Traits index mean } \\
\text { Panels coverage Outer } \\
\text { Panels coverage Inner } \\
\text { Prevalence index mean } \\
\text { Resistance to copper } \\
\text { Resistance to pollutants } \\
\text { Resistance index mean }\end{array}$ & $\begin{array}{l}9.37 \pm 0.00 \\
0.33 \pm 0.00 \\
1.22 \pm 0.00 \\
0.128 \pm 0.01 \\
2.454 \pm 0.05 \\
26.5 \pm 1.27 \\
19.75 \pm 0.42 \\
1.27 \pm 0.02 \\
2.29 \pm 0.03 \\
0.11 \pm 0.01 \\
0.08 \pm 0.02 \\
0.6 \\
1\end{array}$ & $\begin{array}{l}10.79 \pm 0.74^{*} \\
0.71 \pm 0.15^{*} \\
1.38 \pm 0.25 \\
0.191 \pm 0.05^{*} \\
2.864 \pm 0.04^{*} \\
45 \pm 0.00^{*} \\
12 \pm 0.00^{*} \\
1.29 \pm 0.08 \\
2.57 \pm 0.09^{*} \\
0.10 \pm 0.00^{*} \\
0.11 \pm 0.01^{*} \\
1 \\
1.07\end{array}$ & $\begin{array}{l}1.152 \pm 0.08 \\
2.152 \pm 0.45 \\
1.131 \pm 0.21 \\
1.494 \pm 0.30 \\
1.167 \pm 0.02 \\
1.698 \pm 0.03 \\
0.608 \pm 0.04 \\
1.010 \pm 0.05 \\
1.122 \pm 0.03 \\
\mathbf{1 . 2 1 4} \pm 0.06 \\
0.928 \pm 0.10 \\
1.427 \pm 0.30 \\
\mathbf{1 . 1 5 1} \pm 0.05 \\
1.667 \\
1.070 \\
\mathbf{1 . 3 3 6} \\
\mathbf{1 . 2 3 1} \pm 0.02\end{array}$ \\
\hline North Sea & $\begin{array}{l}\text { Prevalence } \\
\text { Resistance } \\
\text { Overall index mean }\end{array}$ & $\begin{array}{l}\text { Growth }\left(\mathrm{L}_{\infty}\right) \\
\text { Growth (K) } \\
\text { Growth ( } \varnothing) \\
\text { Length-Weight (a) } \\
\text { Length-Weight (b) } \\
\text { Bending (degrees) } \\
\text { Salinity (psu) } \\
\text { Growth pattern } \\
\text { Hydrodynamic resistance } \\
\text { Traits index mean } \\
\text { Panels coverage Outer } \\
\text { Panels coverage Inner } \\
\text { Prevalence index mean } \\
\text { Resistance to copper } \\
\text { Resistance to pollutants } \\
\text { Resistance index mean }\end{array}$ & $\begin{array}{l}9.37 \pm 0.00 \\
0.33 \pm 0.00 \\
1.22 \pm 0.00 \\
0.103 \pm 0.01 \\
2.746 \pm 0.04 \\
28.18 \pm 1.18 \\
19.75 \pm 0.41 \\
1.39 \pm 0.02 \\
2 \pm 0.04 \\
0.12 \pm 0.01 \\
0.07 \pm 0.01 \\
0.6 \\
1\end{array}$ & $\begin{array}{l}9.76 \pm 0.18^{*} \\
0.55 \pm 0.03^{*} \\
1.47 \pm 0.05^{*} \\
0.101 \pm 0.03 \\
2.932 \pm 0.02^{*} \\
33.33 \pm 2.77^{*} \\
12 \pm 0.00^{*} \\
1.27 \pm 0.02^{*} \\
2.48 \pm 0.11^{*} \\
0.10 \pm 0.01^{*} \\
0.07 \pm 0.00 \\
1 \\
1.07\end{array}$ & $\begin{array}{l}1.042 \pm 0.02 \\
1.667 \pm 0.10 \\
1.205 \pm 0.04 \\
0.977 \pm 0.19 \\
1.068 \pm 0.01 \\
1.183 \pm 0.07 \\
0.608 \pm 0.03 \\
0.910 \pm 0.01 \\
1.240 \pm 0.02 \\
\mathbf{1 . 0 6 6} \pm 0.04 \\
0.833 \pm 0.06 \\
1.000 \pm 0.14 \\
\mathbf{0 . 9 1 3} \pm 0.06 \\
1.667 \\
1.070 \\
\mathbf{1 . 3 3 6} \\
\mathbf{1 . 0 9 1} \pm 0.02\end{array}$ \\
\hline $\begin{array}{l}\text { Western } \\
\text { Mediterran } \\
\text { ean Sea }\end{array}$ & $\begin{array}{l}\text { Resistance } \\
\text { Overall index mean }\end{array}$ & $\begin{array}{l}\text { Growth }\left(\mathrm{L}_{\infty}\right) \\
\text { Growth }(\mathrm{K}) \\
\text { Growth }(\varnothing) \\
\text { Length-Weight (a) } \\
\text { Length-Weight (b) } \\
\text { Bending (degrees) } \\
\text { Salinity (psu) } \\
\text { Growth pattern } \\
\text { Hydrodynamic resistance } \\
\text { Traits index mean } \\
\text { Panels coverage Outer } \\
\text { Panels coverage Inner } \\
\text { Prevalence index mean } \\
\text { Resistance to copper } \\
\text { Resistance to pollutants } \\
\text { Resistance index mean }\end{array}$ & $\begin{array}{l}10.03 \pm 0.27 \\
0.41 \pm 0.01 \\
1.52 \pm 1.26 \\
0.092 \pm 0.01 \\
2.685 \pm 0.03 \\
40 \pm 1.72 \\
13.7 \pm 0.43 \\
1.29 \pm 0.02 \\
2.37 \pm 0.03 \\
0.11 \pm 0.01 \\
0.06 \pm 0.01 \\
0.6 \\
1\end{array}$ & $\begin{array}{l}9.16 \pm 0.25^{*} \\
0.64 \pm 0.23 \\
1.26 \pm 0.22 \\
0.191 \pm 0.00^{*} \\
2.864 \pm 0.00^{*} \\
27.5 \pm 12.37 \\
10 \pm 0.00^{*} \\
1.00 \pm 0.00^{*} \\
2.8 \pm 0.11^{*} \\
0.17 \pm 0.05^{*} \\
0.08 \pm 0.04 \\
1 \\
1.07\end{array}$ & $\begin{array}{l}0.913 \pm 0.02 \\
1.561 \pm 0.44 \\
0.829 \pm 0.11 \\
2.087 \pm 0.04 \\
1.067 \pm 0.01 \\
0.688 \pm 0.24 \\
0.727 \pm 0.04 \\
0.770 \pm 0.02 \\
1.181 \pm 0.03 \\
\mathbf{1 . 0 2 1} \pm 0.05 \\
1.545 \pm 0.33 \\
1.333 \pm 0.49 \\
\mathbf{1 . 4 3 5} \pm 0.23 \\
1.667 \\
1.070 \\
\mathbf{1 . 3 3 6} \\
\mathbf{1 . 2 5 1} \pm 0.06 \\
\end{array}$ \\
\hline
\end{tabular}

TABLE 1. Summary of index factors by parameter and sea area comparing mean values for parameters computed for native vs NIS found in biofouling in each area. All means are geometric means \pm standard deviation values, which were calculated using a 'leaving one out' schema and provide an uncertainty estimate. No standard deviation is shown for the resistance factors because these values were extracted from the literature.

(*) indicates NIS values significantly different $(\mathrm{p}>0.01)$ using a paired t-test. 


\section{Measured costs of mitigation measures (anti-fouling and BWTS)}

After grouping ships in categories, initial estimates of costs of mitigation measures (Table 2) were determined based on the limited information that is publically available (Asariotis $e t$ al., 2012; US Department of Transportation Maritime Administration, 2011; Anwar, 2011; Kalli et al., 2009; AECOM, 2012; Smith, 2013). Due to the paucity of information, these have to be considered as guideline ranges of proportional costs, and are used here to simply support this approach and promote the need for further research and collaboration with the shipping industry. Additional costs due to personal training or increase in maintenance and insurance costs are not considered.

\begin{tabular}{|c|c|c|c|c|}
\hline & & $\begin{array}{l}\text { CATEGORY } 1 \\
\text { Fishing Vessels } \\
\text { Offshore Support Vessels }\end{array}$ & $\begin{array}{l}\text { CATEGORY } 3 \\
\text { Container Ships } \\
\text { General Cargo Ships } \\
\end{array}$ & $\begin{array}{l}\text { CATEGORY } 5 \\
\text { Bulk Carriers } \\
\text { Tankers } \\
\end{array}$ \\
\hline & & CATEGORY 2 & CATEGORY 4 & CATEGORY 6 \\
\hline & & Passenger Ships & Refrigerated Cargo Ships & Container Ships \\
\hline & & Passenger Cruise Ships & Cargo Ships (Ro-Ro) & General Cargo Ships \\
\hline & & $\begin{array}{l}\text { Passenger / Cargo Ships } \\
\text { (Ro-Ro) }\end{array}$ & $\begin{array}{l}\text { Livestock / Vehicle } \\
\text { Carriers }\end{array}$ & \\
\hline BWT & olume capacity & $<1500 \mathrm{~m}^{3}$ & $1500-5000 \mathrm{~m}^{3}$ & $>5000 \mathrm{~m}^{3}$ \\
\hline BWT & umping capacity & $<150 \mathrm{~m}^{3} \mathrm{~h}^{-1}$ & $150-500 \mathrm{~m}^{3} \mathrm{~h}^{-1}$ & $>500 \mathrm{~m}^{3} \mathrm{~h}^{-1}$ \\
\hline Dead & ght tonnage & $<10000$ & $<30000$ & $30000-325000$ \\
\hline Numl & of ships & 16158 & 21059 & 28424 \\
\hline$\%$ shi & in BWTS category & 96.7 & 97.48 & 95.1 \\
\hline$\%$ shi & in world fleet & 23.7 & 30.88 & 41.68 \\
\hline DC & \%Anti-fouling & $0.57-0.34$ & $0.76-0.33$ & $0.77-0.25$ \\
\hline & $\%$ increase BWTS & $2.01-1.53$ & $2.12-1.58$ & $2.10-1.22$ \\
\hline & Total \% MM & $2.58-1.89$ & $2.88-1.91$ & $2.87-1.47$ \\
\hline Non- & \% Anti-fouling & $0.76-0.40$ & $1.01-0.36$ & $1.06-0.28$ \\
\hline DC & $\%$ increase BWTS & $2.70-1.83$ & $2.12-1.58$ & $2.90-1.36$ \\
\hline & Total \% MM & $3.46-2.23$ & $3.13-1.94$ & $3.96-1.64$ \\
\hline & Surveys anti-fouling & $5-10 \%$ & & $1-3 \%$ \\
\hline
\end{tabular}

TABLE 2. Estimated proportion of the overall costs of shipping that mitigation measures (MM) will represent with new legislation and guidelines implemented in the coming years. The table shows a column for each BWTS volume capacity, the common pumping capacity and tonnage in these categories as well as the type of ships that commonly fall in these BWTS capacities. Statistics about the number of ships and the proportion these represent in relation to the rest of ships that have BWTS in each capacity and in relation to the full fleet with BWTS are presented. Costs are split into those allocated to anti-fouling MMs and those for installing and operating a BWTS. The last row ("Surveys anti-fouling") corresponds to estimates of the proportional costs of 
anti-fouling MMs provided by some of the surveyed industries. Finally, DC - Developed country; non-DC non-developed country.

For the purposes of comparison we have further divided the shipping industry into two cost types based on U.S. Department of Transportation Maritime Administration report (2011): 1) US as an example of a developed country, where costs can be twice those of less developed countries; this is partly due to labour costs which can be as much as 4 times higher in developed countries; 2) less developed countries where the shipping industry is characterized by a higher proportion of capital cost in their cost structure. Yet, the costs of mitigation measures represent a higher proportion of the overall cost of the shipping in less developed countries. It seems likely that the European shipping industry is closer to the developed country cost structure (U.S.) than that of the developing country shipping industry, or somewhere in between. In every case, the proportion of costs associated with anti-fouling measures is smaller than those associated with BWTS (Table 2), but the survey respondents gave higher estimates. This could be due to systematic underestimation in our methodology or because surveys provided an estimated and hence more approximate value.

Six specific ship case studies from the surveys of the shipping industry are also considered here to contrast with the generic results (Table 3). The percentage costs of mitigation measures are highest in the smaller ships. An economy of scale is observed regarding the larger ships which also have much higher operating costs.

\begin{tabular}{lllllll}
\hline Type of ship & Bulk Carrier & $\begin{array}{l}\text { Offshore } \\
\text { Support } \\
\text { Vessel }\end{array}$ & Dredger & $\begin{array}{l}\text { Ro-Ro Cargo } \\
\text { Ship }\end{array}$ & $\begin{array}{l}\text { General } \\
\text { Cargo Ship }\end{array}$ & $\begin{array}{l}\text { Crude Oil } \\
\text { Tanker }\end{array}$ \\
\hline $\begin{array}{l}\text { Category (from } \\
\text { Table 1) }\end{array}$ & 1 & 1 & 1 & 4 & 5 & 5 \\
\hline DWT & 1100 & 2600 & 12304 & 31340 & 73000 & 113000 \\
\hline \% Anti-fouling & 0.07 & 0.05 & 0.13 & 0.35 & 0.04 & 0.03 \\
\% increase BW & 9.91 & 3.87 & 1.23 & 0.88 & 0.33 & 0.33 \\
Total \% MM & 9.99 & 3.92 & 1.35 & 1.22 & 0.37 & 0.36 \\
\hline
\end{tabular}


TABLE 3. Percentage of annual cost (operating and capital amortization) that mitigation measures (MM) will represent with new legislation and guidelines implemented on the six specific ship case studies from literature and our survey of the shipping industry. The first two case studies (columns) are based on costs reported in the case studies source publication (Smith, 2013); when other costs for small ships reported in the literature are considered, the values reported in this table (9.99 and 3.92) drop to 1.42 and 1.25 . This might be due to the heterogeneity of ships, differences of cost depending on the operating country or high uncertainty on reported costs.

The current work also indicates some very general similarities in costs within some types of shipping activity. This could imply differential impacts on costs for transported goods depending on the type of ship. The share of the full production cost represented by transportation differs between categories of goods transported. For example, on average the proportion of full production cost represented by maritime transport for raw materials, agricultural goods, manufactured goods and crude oil is $24.2 \%, 10.9 \%, 5.1 \%$ and $4 \%$ respectively (Korinek and Sourdin, 2009). However, the impact could be higher in other enterprises such as passenger ships or fishing. Moreover, there could be other unintended and undesirable consequences of higher costs for shipping caused by mitigation measures such as small shipping businesses going bankrupt which could lead to a reduction in sea transport and corresponding increase in land transportation (Smith et al., 2013). This can lead to further contamination of already-polluted routes and additional traffic congestion. This potential cascade illustrates the complexity of the interactions between the environment, economy and impact on society, which justifies further work to improve our understanding of the associated environmental and economic trade-offs. 


\section{DISCUSSION}

Uncertainties, limitations and assumptions in this study. There are limitations to the data available in terms of species traits and shipping industry costs. The presence of data for each of the species traits in the literature and databases ranged from $4.5 \%$ to $41 \%$ across native species and between $9.1 \%$ and $18.2 \%$ across NIS. The data on biofouling of panels included $45.8 \%$ of the problematic species considered. The inclusion of macroalgae was limited to three species that are particularly important in early fouling, but other biofouling algae could be relevant (Mineur, 2007; 2012). Similarly, public access to shipping industry data is very limited. Accurately calculating the economic influence of NIS on the shipping industry relies partly on obtaining information about the inherent costs of commercial vessel operation which is not readily available to those outside the industry. Our pilot survey of ship owners has provided limited, yet valuable information but this now needs to be substantiated across the categories of vessels identified here, to provide more confidence in the representativeness of these data. Faced with such data shortages, this study does not attempt to provide a full explanation of the link between NIS and shipping industry economics, but instead presents an estimation framework based on indices which can be applied to address this important question as more data become available. The numbers provided are not to be considered more than an aid to help the discussion of the complexity and the inter-linkages between different scientific disciplines and stakeholders.

Fuel consumption and cost due to NIS. It remains to be seen whether the aggregated factor index by regional sea, calculated using the geometric mean of all the indices (1.231, 1.091 and 1.251 for Baltic, North and Western Mediterranean Sea respectively) could at some stage in the future be realistically converted into a percentage increase in fuel consumption due to NIS for each region. At best, we could expect that fuel consumption could be influenced by the overall NIS index as a monotonic function, but there is no reason to 
suppose it would be directly proportional (even if there were no other variables to influence fuel use). Therefore, at the present time, this expectation is not sufficiently supported by our analysis alone as any translation to fuel consumption would need to be weighted based on experimental work or sampling in different kinds of ships, and according to other factors involved in fuel consumption, such as antifouling coating type and age, cleaning procedures, vessel performance monitoring equipment etc. However, the approach we have used provides an indication that the potential scale of impact is similar across the regional seas. Future refinement of this approach could contribute to an estimate of the potential increase in fuel consumption in each sea due to NIS. In the next section we estimate the cost of mitigation measures in relation to total yearly costs, for comparison with the likely impact of NIS that we just investigated.

Anti-fouling costs. Literature reviews and expert consultation indicated that a large number of different antifouling paints have been designed to meet different operational profiles (Readman, 2006; Herberg et al., 2009; Daforn et al., 2011) and similarly that there are a large number of cleaning measures to suit different paint technologies. Therefore, expert consultation and our shipping survey were used to identify the specific practices of different shipping industries. Interviews with 5 experts along with 6 shipping company surveys suggest that ships within the identified categories employ similar practices and have similar needs in terms of mitigation measures. For example, smaller ships tend to use cheaper antifouling coatings that require recoating or repair every 2 to 3 years, whereas a company utilising larger vessels reported using better-performing coatings and also undertaking periodic underwater cleaning of the surfaces to maintain the effectiveness of the applied antifouling coating for up to 5 years. This is probably due to the economies of scale in the shipping industry where, with more distance travelled and commodities transported, more expensive but efficient control measures can be used to lower unit cost. For the purposes of 
discussion, it has been assumed that this principle can be generally applied to all ships of the same category. Fuel consumption cost is mostly driven by speed and other factors that can be related to cargo capacities (e.g. dead weight tonnage; DWT) and the definitions of our 6 categories of cargo type (Notteboom and Cariou, 2009; Ronen et al., 2011). Furthermore, BWTS costs are related to the pumping capacity required, which is correlated with both the total BW volume (Fig. 2a) and DWT (Fig 2b) of the ships (Anwar et al., 2011).
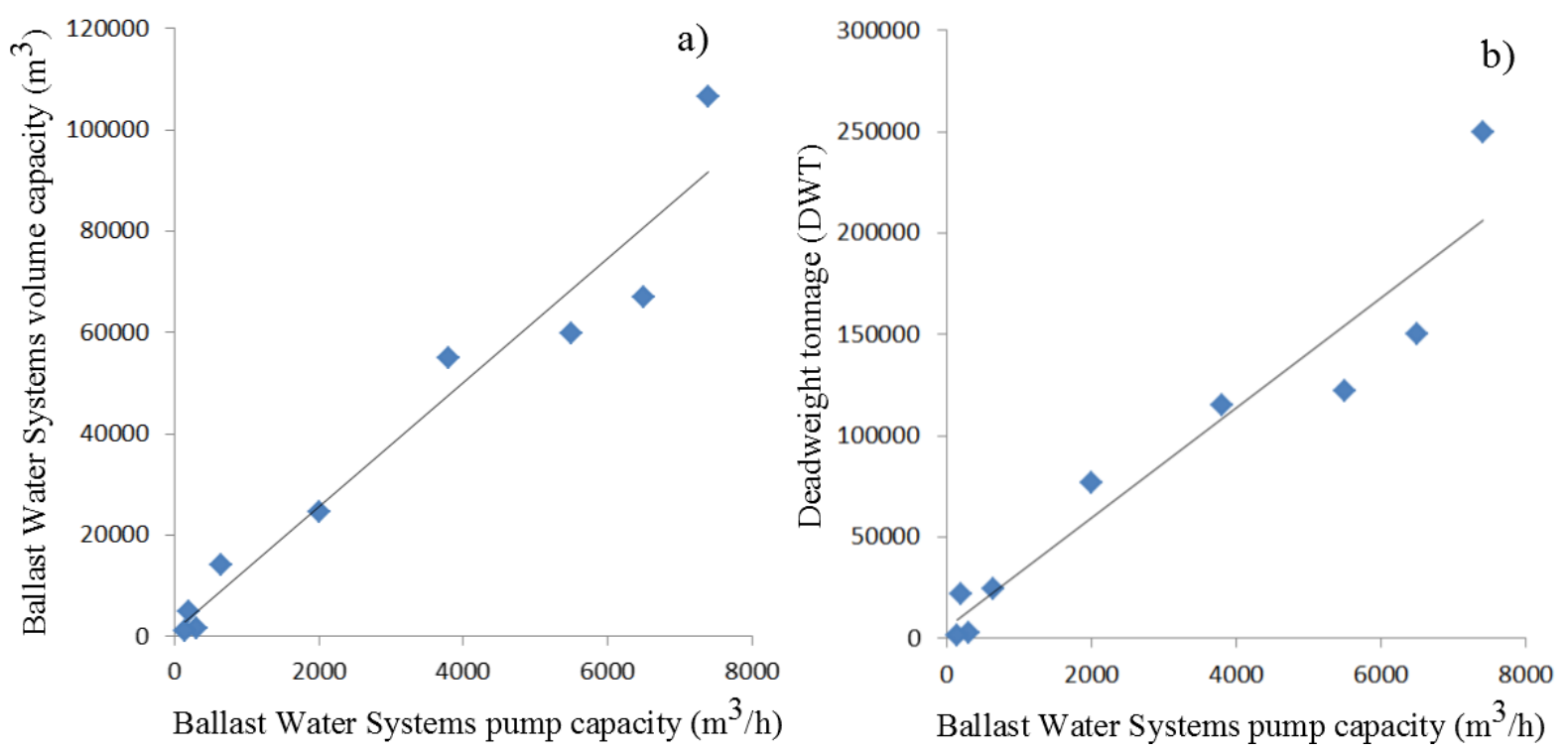

FIGURE 2. a) the relationship between ballast water pumping capacity and the ballast water volume capacity; and, b) the relationship between ballast water pumping capacity and DWT.

Costs of ballast water treatment systems. The operational cost of BWTS is mostly driven by pumping capacity which is linked to volume capacity and to DWT. After speed, fuel consumption is most strongly related to DWT. The shipping industry has various strategies to reduce its fuel costs. These include using bigger ships that can carry 3 times more load but have only double the fuel consumption (Notteboom and Cariou, 2009; AECOM, 2012). There is evidence that this strategy has not been used much recently due to the Western financial crisis. Another strategy is to reduce speed to the minimum possible that 
efficiently saves fuel (Smith, 2013; Rodrique, 2013). This brings about other benefits such as the reduction of emissions and thus lower impacts on human health (Fuglestvedt et al., 2009; Borken-Kleefeld et al., 2010). However, this measure could lead to increased biofouling, as antifouling coatings are generally designed to perform better at higher speeds (Rattenbury, 2008).

Response of the industry. Regarding BWTS, the shipping industry is generally installing systems in new-build ships or leaving space for retro-fits at a later date. The industry is being cautious by installing systems in only a small proportion of their ships in order to get operational experience that can inform future investment. The expectation is that the prices of BWTS will remain low until the legislation is fully ratified. There is considerable uncertainty about what will happen when the IMO Ballast Water Management Convention is enforced. It is expected that the costs of BWTS purchase and installation will increase due to high demand. However, this might be counteracted by the fact that the time period to install the systems has been extended from 4 to 6 years. In addition, there is likely to be an increase in competition between BWTS suppliers as more systems come into the market. The decision about which system to install is moving from being based on the cost of the system to the cost of operating it in terms of energy consumption, even if this is relatively small in comparison. This can be understood since there are economies of scale (for some large industries), where small changes in operating cost can make a big difference to annual profits. Moreover, due to the recent worldwide economic crisis, many ships might have been operating at a loss. 


\section{CONCLUSIONS}

Despite the limitations imposed by scarcity of available data, our study suggests that NIS fouling species have a higher impact on fuel consumption than native species. Moreover, the uncertainty analysis shows that the variability of the results is smaller than the range of the effects observed. Therefore, limiting the vectors for NIS is important not only for the environment and coastal ecosystems, but also for the future operational costs of the global shipping industry. It is also shown here that mitigation measures can be a significant burden on the industry, particularly for smaller vessels where operating margins are substantially lower because in general terms they carry lower-value cargos. However, the largest vessels in the industry, exploiting economies of scale, can also be highly influenced by relatively small cost increases due to their operational cost structure and competition within the charter market place. However, in the medium to long term, the costs incurred may be viewed as positive investments if they prevent or mitigate the spread of NIS. It is also likely that over longer time scales there will be significant advances in both antifouling and ballast water treatment technology that will alter the balance of investment described here. It is proposed that the approach presented here can provide a useful indication of the changing costs of NIS to the shipping industry. Finally, this work has highlighted the need for a joint industry project to fully address the lack of information on this subject. We believe that working with a willing partner (or group of partners) who operates a significant number of ships would facilitate a quantitative study that would better verify our estimates and suppositions from this work. 


\section{ACKNOWLEDGEMENTS}

The research leading to these results has received funding from the European Community's Seventh Framework Programme (FP7/2007-2013) under Grant Agreement No. 266445 for the project Vectors of Change in Oceans and Seas Marine Life, Impact on Economic Sectors (VECTORS). John Bishop and Frédérique Viard acknowledge support from the Interreg IVa Marinexus programme. We thank all the industry members that answered our surveys and other experts who have provided some input to this work. In particular, we thank staff and scientists involved with the AquaNIS database for providing data, and those that support other public databases such as SeaLifeBase, MarBEF, WoRMS, BIOTIC and the database found in Natural England. We express our gratitude to Tobias Börger for his advice on the initial design of the survey of the shipping industry. 


\section{REFERENCES}

AECOM. NC Maritime strategy Vessel Size vs Cost. In N.C. Maritime Study Document Library (Eds.). North Carolina Department of transportation: N.C., 2012.

Anwar, N. (Captain). Ballast water management: Understanding the regulations and the various treatment technologies, 2nd ed.; Witherby Publishing Group: Edinburgh, 2011.

Asariotis, R.; Benamara, H.; Finkenbrink, H.; Hoffmann, J.; Jaimurzina, A.; Premti, A.; Valentine, V.; Youssef, F. Review of Maritime Transport 2012; United Nations, United Nations Conference on Trade and Development (UNCTAD), Trade Logistics Branch of the Division on Technology and Logistics: Geneva, Switzerland, 2012, pp 19.

Bax, N.; Williamson, A.; Aguero, M.; Gonzalez, E.; Geeves, W. Marine invasive alien species: a threat to global biodiversity. Marine policy. 2003, 27(4), 313-323.

Berntzen, M. Guidelines for selection of a ship ballast water treatment system. M.Sc. Thesis, Norwegian University of Science and Technology, Trondheim, Norway, 2011.

Borken-Kleefeld, J.; Berntsen, T.; Fuglestvedt, J. Specific climate impact of passenger and freight transport. Environ. Sci. Technol. 2010, 44 (15), 5700-5706.

Brown, R. J.; Woods, P. T. Comparison of averaging techniques for the calculation of the 'European average exposure indicator' for particulate matter. J. Environ. Monitor. 2012, 14 (1), 165-171.

Cheung, W. W. L.; Lam, V.; Sarmiento, J. L.; Kearney, K.; Watson, R.; Pauly, D. Projecting global marine biodiversity impacts under climate change scenarios. Fish Fish. 2009, 10, 235-251.

Colautti, R. I.; Macisaac, H. J. A neutral terminology to define 'invasive' species. Divers. Distrib. 2004, 10, $135-141$.

Crooks, J. A.; Chang, A. L.; Ruiz, G. M. Aquatic pollution increases the relative success of invasive species. Biol. Invasions. 2011, 13 (1), 165-176.

Dafforn, K. A.; Lewis, J. A.; Johnston, E. L. Antifouling strategies: History and regulation, ecological impacts and mitigation. Mar. Pollut. Bull. 2011, 62 (3), 453-465.

Fernandes J.A., Irigoien X., Boyra G., Lozano J.A., Inza I. Optimizing the number of classes in automated zooplankton classification. J. Plankton Res. 200931 (1), 19-29.

Fernandes, J. A.; Irigoien, X.; Goikoetxea, N.; Lozano, J. A.; Inza, I.; Pérez, A.; Bode, A. Fish recruitment prediction, using robust supervised classification methods. Ecol. Model. 2010, 221 (2), 338-352.

Fernandes, J. A.; William, W. L. C.; Jennings, S.; Butenschön, M.; De Mora, L.; Frölicher, T. L.; Barange, M.; Grant, A. Modelling the effects of climate change on the distribution and production of marine fishes: Accounting for trophic interactions in a dynamic bioclimate envelope model. Glob. Change Biol. 2013, 19, 2596-2607.

Floerl, O.; Pool, T. K.; Inglis, G. J. Positive interactions between non-indigenous species facilitate transport by human vectors. Ecol. Appl. 2004, 14, 1724-1736.

Fuglestvedt, J.; Berntsen, T.; Eyring, V.; Isaksen, I.; Lee, D. S.; Sausen, R. Shipping emissions: From cooling to warming of climate and reducing impacts on health. Environ. Sci. Technol. 2009, 43 (24), 9057-9062.

Galton, F. The geometric mean, in vital and social statistics. In Proceedings of the Royal Society of London, London, U.K., 1879, 29 (196-199), 365-367.

Gollasch, S. The importance of ship hull fouling as a vector of species introductions into the North Sea. Biofouling. 2002, 18 (2), 105-121.

Herzberg, M.; Kang, S.; Elimelech, M. Role of extracellular polymeric substances (EPS) in biofouling of reverse osmosis membranes. Environ. Sci. Technol. 2009, 43 (12), 4393-4398.

Hulme, P. E. Trade, transport and trouble: managing invasive species pathways in an era of globalization. $J$. Appl. Ecol. 2009, 46, 10-18.

IMO, MEPC 2011, MEPC.207 (62), 2011 Guidelines for the control and management of ships' biofouling to minimize the transfer of Invasive aquatic species. MEPC 62/24/Add.1, Annex 26, page 1; International Maritime Organization: London, July 2011, 25 pp.

IMO, MEPC 2012, MEPC.1/Circ.792, Guidance for minimizing the transfer of invasive aquatic species as biofouling (hull fouling) for recreational craft. MEPC 64/23 (see annex 5 of document BLG 16/16). International Maritime Organization: London, November 2012, 5 pp.

Kalli, J.; Karvonen, T.; Makkonen, T. Sulphur content in ships bunker fuel in 2015. A study on the impacts of the new IMO regulations on transportation costs; Report assigned by the Ministry of Transport and Communications; University of Turku: Turku, Finland, 2009.

Karatayev, A. Y.; Burlakova, L. E.; Padilla, D. K.; Mastitsky, S. E.; Olenin, S. Invaders are not a random selection of species. Biol. Invasions. 2009, 11 (9), 2009-2019.

King, D. M.; Hagan, P. T.; Riggio, M.; Wright, D. A. Preview of global ballast water treatment markets. Journal of Marine Engineering and Technology. 2012, 11 (1), 3-15. 
Korinek, J.; Sourdin, P. Maritime transport costs and their impact on trade. OECD working paper TAD/TC/WP2009-7. 2009.

Leppäkoski, E.; Olenin, S. Non-native species and rates of spread: Lessons from the brackish Baltic Sea. Biol. Invasions. 2000, 2, 151-163.

Liu, T. K.; Chang, C. H.; Chou, M. L. Management strategies to prevent the introduction of non-indigenous aquatic species in response to the Ballast Water Convention in Taiwan. Marine Policy. 2014, 44, 187-195.

McCarthy, S.A., Khambaty, F.M. International dissemination of epidemic Vibrio cholerae by cargo ship ballast and other nonpotable waters. Applied and Environmental Microbiology, 1994, 60, 2597-2601.

Mineur, F.; Belsher, T.; Johnson, M. P.; Maggs, C. A.; Verlaque, M. Experimental assessment of oyster transfers as a vector for macroalgal introductions. Biol. Cons. 2007, 137 (2), 237-247.

Mineur, F.; Johnson, M. P.; Maggs, C. A.; Stegenga, H. Hull fouling on commercial ships as a vector of macroalgal introduction. Mar. Biol. 2007, 151 (4), 1299-1307.

Mineur, F.; Cook, E. J.; Minchin, D.; Bohn, K.; MacLeod, A.; Maggs, C. A. Changing coasts: marine aliens and artificial structures. Oceanogr. Mar. Biol. 2012, 50, 189-233.

Minchin, D.; Gollasch, S. Fouling and ships' hulls: how changing circumstances and spawning events may result in the spread of exotic species. Biofouling, 2003, 19 (Suppl.), 111-122.

Mitchell, D. W. More on spreads and non-arithmetic means. Math. Gaz. 2004, 88, 142-144.

Mosteller, F.; Tukey, J.F. Data analysis, including statistics. In: Lindzey, G., Aronson, E. (Eds.), Handbook of Social Psychology, vol. II. Addison-Wesley, Reading, MA, p. 588, 1968.

Nadeau, C.; Bengio, Y. Inference for the generalization error. Mach. Learn. 2003, 52, 239-281.

Notteboom, T.; Cariou, P. Fuel surcharge practices of container shipping lines: Is it about cost recovery or revenue-making?. In Proceedings of the 2009 International Association of Maritime Economists (IAME) Conference, Copenhagen, Denmark, June, 2009.

Olenin, S.; Minchin, D.; Daunys, D.; Zaiko, A. Pathways of aquatic invasions in Europe. In Atlas of Biodiversity Risk; Settele, J., Penev, L. D., Georgiev, T. A., Grabaum, R., Grobelnik, V., Hammen, V., Klotz, S., Kotarac, M., Kühn, I., Eds.; Pensoft Publishers: 2010, pp 138-139.

Paavola, M.; Olenin, S.; Leppäkoski, E. Are invasive species most successful in habitats of low native species richness across European brackish water seas?. Est. Coast. Shelf Sci. 2005, 64, 738-750.

Pereira, H. M.; Leadley, P. W.; Proença, V.; Alkemade, R.; Scharlemann, J. P.; Fernandez-Manjarrés, J. F.; Araújo, M. B.; Balvanera, P.; Biggs, R.; Cheung, W. W.; Chini, L.; Cooper, H. D.; Gilman, E. L.; Guénette, S.; Hurtt, G. C.; Huntington, H. P.; Mace, G. M.; Oberdorff, T.; Revenga, C.; Rodrigues, P.; Scholes, R. J.; Sumaila, U. R.; Walpole, M. Scenarios for global biodiversity in the 21st century. Science. 2010, 330 (6010).

Perrings, C., Mooney, H., Williamson, M., Eds. Bioinvasions \& Globalization - Ecology, Economics, Management and Policy; Oxford University Press: Oxford, 2010.

Pimentel, D.; Zuniga, R.; Morrison, D. Update on the environmental and economic costs associated with alieninvasive species in the United States. Ecol. Econ. 2005, 52 (3), 273-288.

Pyefinch, K. A. The biology of ship fouling; New Biology: London, U.K., pp. 128-149, 1954.

Rahel, F. J.; Olden J. D. Assessing the effects of climate change on aquatic invasive species. Conserv. Biol. 2008, 22, 521-533.

Rattenbury, N. Is slow speed operation a panacea for reliable ship operation?. In: Container ship speed matters; Tozer, D., Ed.; Lloyd's Register, London, September, 2008, pp 11-12.

Readman, J. W. Development, occurrence and regulation of antifouling paint biocides: Historical review and future trends. In Antifouling Paint Biocides; Konstantinou, I. K., Ed.; Springer-Verlag Berlin Heidelberg: 2006; pp 1-15.

Redfield, A.C.; Hutchins, L. W.; Deevy, E. S.; Ayers, J. C.; Turner, H. J.; Laidlaw, F. B.; Ferry, J. D.; Todd, D. Marine fouling and its prevention. In Redfield, A. C. \& Ketchum, B. H., Eds.; Bd. 580, George Banta Inc., Menasha 1952; pp 388.

Reise, K.; Gollasch, S.; Wolff, W. J. Introduced marine species of the North Sea coasts. Helgol. Meeresunters. 1999, 52, 219-234.

Rilov, G., Crooks, J. A., Eds. Biological Invasions in Marine Ecosystems: Ecological, Management, and Geographic Perspectives; Springer-Verlag Berlin Heidelberg: New York, 2009.

Roberts, J.; Tsamenyi, M. International legal options for the control of biofouling on international vessels. Marine Policy. 2008, 32(4), 559-569.

Rodríguez, J. D.; Pérez, A.; Lozano, J. A. A general framework for the statistical analysis of the sources of variance for classification error estimators. Pattern Recogn. 2013 , 46 (3), 855-864.

Rodrique, J. P. (ed.). The Geography of Transport Systems, 3rd, ed.; Hofstra University, Department of Global Studies \& Geography: New York, USA, 2013. Available from http://www.people.hofstra.edu/geotrans/ (accessed January 24, 2014).

Ronen, D. The effect of oil price on containership speed and fleet size. J. Oper. Res. Soc. 2011, 62 (1), 211-216. 
Sarà, G.; Martire, M. L.; Buffa, G.; Mannino, A. M.; Badalamenti, F. The fouling community as an indicator of fish farming impact in Mediterranean. Aquacult. Res. 2007, 38 (1), 66-75.

Schernewski, G., Schippmann, B., \& Walczykiewicz, T. Coastal bathing water quality and climate change - A new information and simulation system for new challenges. Ocean \& Coastal Management, 2014, 101, 5360.

Scriven, D. R.; DiBacco, C.; Locke, A.; Therriault, T. W. Ballast water management in Canada: A historical perspective and implications for the future. Marine Policy. 2015, 59, 121-133.

Simkanin, C.; Davidson, I.; Falkner, M.; Sytsma, M.; Ruiz, G. Intra-coastal ballast water flux and the potential for secondary spread of non-native species on the US west coast. Mar. Pollut. Bull. 2009, 58, 366-374.

Smith, D. Ballast fears for small ships. Nautilus International Telegraph, February 2013, 47 (2), p 30.

Smith, T. W. P.; O'Keeffe, E.; Aldous, L.; Agnolucci, P. Assessment of Shipping's Efficiency Using Satellite AIS data; UCL Energy Institute: London, 2013.

Swain, G. W.; Kovach, B.; Touzot, A.; Casse, F.; Kavanagh, C. J. Measuring the performance of today's antifouling coatings. Journal of Ship Production, 2007, 23 (3), 164-170.

Sylvester, F.; Kalaci, O.; Leung, B.; Lacoursière-Roussel, A.; Murray, C. C.; Choi, F. M.; Bravo, M. A.; Therriault, T. W.; MacIsaac, H. J. Hull fouling as an invasion vector: can simple models explain a complex problem?. J. Appl. Ecol. 2011, 48 (2), 415-423.

US Coast Guard Final Rule March 23, 2012 - effective from June 21, 2012. Website http://www.uscg.mil/hq/cg5/cg522/cg5224/bwm.asp.

US Department of Transportation Maritime Administration. Comparison of US and foreign-flag operating costs; In Federal Research News. Transportation Research Board (eds.): Washington, D.C., September 2011.

US EPA 'Vessel General Permit' now includes ballast water treatment provisions; published 28 March, 2013. Website http://cfpub.epa.gov/npdes/vessels/vgpermit.cfm

Vilà, M.; Basnou, C.; Pyšek, P.; Josefsson, M.; Genovesi, P.; Gollasch, S.; Nentwig, W.; Olenin, S.; Roques, R.; Roy, D.; Hulme, P. E. and DAISIE partners. How well do we understand the impacts of alien species on ecosystem services? A pan-European cross-taxa assessment. Front. Ecol. Environ. 2010, 8, 135-144.

Vilà, M.; Espinar, J. L.; Hejda, M.; Hulme, P. E.; Jarošík, V.; Maron, J. L.; Pergl, J.; Schaffner, U.; Sun, Y.; Pyšek, P. Ecological impacts of invasive alien plants: A meta-analysis of their effects on species, communities and ecosystems. Ecol. Lett. 2011, 14 (7), 702-708.

Yoon B. B. Ballast Water Treatment: Solutions and cost implications. World Ship Registry Conference, Singapore, 2011. 
APPENDIX 1. List of identified problematic species in relation to fuel consumption for shipping industry.

\begin{tabular}{|c|c|c|c|}
\hline Species & Category & Class & Family \\
\hline Amphibalanus amphitrite & Acorn Barnacles & Maxillopoda & Balanidae \\
\hline Amphibalanus improvisus & Acorn Barnacles & Maxillopoda & Balanidae \\
\hline Ascidia mentula & Tunicates & Ascidiacea & Ascidiidae \\
\hline Ascidiella aspersa & Tunicates & Ascidiacea & Ascidiidae \\
\hline Ascidiella scabra & Tunicates & Ascidiacea & Ascidiidae \\
\hline Asterocarpa humilis & Tunicates & Ascidiacea & Styelidae \\
\hline Austrominius modestus & Acorn Barnacles & Maxillopoda & Austrobalanidae \\
\hline Balanus balanus & Acorn Barnacles & Maxillopoda & Balanidae \\
\hline Balanus crenatus & Acorn Barnacles & Maxillopoda & Balanidae \\
\hline Balanus trigonus & Acorn Barnacles & Maxillopoda & Balanidae \\
\hline Botrylloides leachii & Tunicates & Ascidiacea & Styelidae \\
\hline Botryllus schlosseri & Tunicates & Ascidiacea & Styelidae \\
\hline Bugula flabellata & Bryozoans & Gymnolaemata & Bugulidae \\
\hline Bugula neritina & Bryozoans & Gymnolaemata & Bugulidae \\
\hline Celleporella hyalina & Bryozoans & Gymnolaemata & Hippothoidae \\
\hline Chthamalus stellatus & Acorn Barnacles & Maxillopoda & Chthamalidae \\
\hline Ciona intestinalis & Tunicates & Ascidiacea & Cionidae \\
\hline Clavelina lepadiformis & Tunicates & Ascidiacea & Clavelinidae \\
\hline Concavus concavus & Acorn Barnacles & Maxillopoda & Balanidae \\
\hline Conchoderma auritum & Goose Barnacles & Maxillopoda & Lepadidae \\
\hline Conchoderma virgatum & Goose Barnacles & Maxillopoda & Lepadidae \\
\hline Cordylophora caspia & Hydroids & Hydrozoa & Cordylophoridae \\
\hline Corella eumyota & Tunicates & Ascidiacea & Corellidae \\
\hline Crassostrea gigas & Molluscs & Bivalvia & Ostreidae \\
\hline Crassostrea virginica & Molluscs & Bivalvia & Ostreidae \\
\hline Cryptosula pallasiana & Bryozoans & Gymnolaemata & Cryptosulidae \\
\hline Diadumene lineata & Anemones & Anthozoa & Haliplanellidae \\
\hline Diplosoma listerianum & Tunicates & Ascidiacea & Didemnidae \\
\hline Diplosoma spongiforme & Tunicates & Ascidiacea & Didemnidae \\
\hline Ectocarpus siliculosus & Algae & Phaeophyceae & Ectocarpaceae \\
\hline Electra pilosa & Bryozoans & Gymnolaemata & Electridae \\
\hline Ficopomatus enigmaticus & Tube Worms (Annelida) & Polychaeta & Serpulidae \\
\hline Jellyella tuberculata & Bryozoans & Gymnolaemata & Membraniporidae \\
\hline Lepas anatifera & Goose Barnacles & Maxillopoda & Lepadidae \\
\hline Lepas anserifera & Goose Barnacles & Maxillopoda & Lepadidae \\
\hline Lepas hillii & Goose Barnacles & Maxillopoda & Lepadidae \\
\hline Megabalanus spinosus & Acorn Barnacles & Maxillopoda & Balanidae \\
\hline Megabalanus tintinnabulum & Acorn Barnacles & Maxillopoda & Balanidae \\
\hline Membranipora membranacea & Bryozoans & Gymnolaemata & Membraniporidae \\
\hline Membranipora tenuis & Bryozoans & Gymnolaemata & Membraniporidae \\
\hline Membraniporella nitida & Bryozoans & Gymnolaemata & Cribrilinidae \\
\hline Mycale rotalis & Sponges & Demospongiae & Mycalidae \\
\hline Mytilus edulis & Molluscs & Bivalvia & Mytilidae \\
\hline Mytilus galloprovincialis & Molluscs & Bivalvia & Mytilidae \\
\hline Palmaria palmata & Algae & Florideophyceae & Palmariaceae \\
\hline Perophora japonica & Tunicates & Ascidiacea & Perophoridae \\
\hline Phallusia mammillata & Tunicates & Ascidiacea & Ascidiidae \\
\hline Pileolaria berkeleyana & Tube Worms (Annelida) & Polychaeta & Serpulidae \\
\hline Scypha compressa & Sponges & Calcarea & Sycettidae \\
\hline Spirobranchus triqueter & Tube Worms (Annelida) & Polychaeta & Serpulidae \\
\hline Spirorbis marioni & Tube Worms (Annelida) & Polychaeta & Serpulidae \\
\hline Styela clava & Tunicates & Ascidiacea & Styelidae \\
\hline Sycon ciliatum & Sponges & Calcarea & Sycettidae \\
\hline Tricellaria inopinata & Bryozoans & Gymnolaemata & Candidae \\
\hline Tubularia indivisa & Hydroids & Hydrozoa & Tubulariidae \\
\hline Ulva lactuca & Algae & Ulvophyceae & Ulvaceae \\
\hline Watersipora arcuata & Bryozoans & Gymnolaemata & Watersiporidae \\
\hline Watersipora aterrima & Bryozoans & Gymnolaemata & Watersiporidae \\
\hline Watersipora subatra & Bryozoans & Gymnolaemata & Watersiporidae \\
\hline
\end{tabular}




\section{Appendix II: Survey regarding}

\section{The costs of invasive species mitigation for the shipping industry}

This survey is being conducted by Plymouth Marine Laboratory for the VECTORS research project (http://www.marine-vectors.eu/). VECTORS, an EU-funded project, would like to try to understand the added cost burden that invasive species have for the shipping industry. We are also interested in your views on the impending IMO ballast water regulations and possible future biofouling regulations.

The questions we ask are designed to:

1. Understand which ballast water treatment system types are in use and their costs (including the true cost of system installation).

2. Understand which biofouling/antifouling controls are in use and their costs (including the true cost of coating and cleaning).

3. Determine the best commercial practices for ballast water treatment and biofouling control with indications on system popularity

4. Understand the real cost burden for specific ships in your fleet

The name of your company and ships featured will remain confidential. If you wish to receive a copy of any publication or report that results from this data please provide your e-mail address or contact information

here:

This questionnaire is ship type specific. However, if you are able to complete a questionnaire for several different types of ship, it would be very much appreciated.

The questionnaire consists of three parts:

Characteristics of the ship you are reporting about 
Cost of anti-fouling measures

Cost of ballast waters systems (if applicable)

Further comments (optional)

Thank you very much for your cooperation! 
1. Please circle the type of ship you are reporting about:
a. Fishing Vessel
i. LNG Tanker
b. Offshore Support Vessel
j. LPG Tanker
c. Passenger Ship
k. Container Ship
d. Passenger Cruise Ship
I. General Cargo Ship e. Passenger/Cargo (Ro-Ro)
Ship
m. Refrigerated Cargo Ship
f. Bulk Carrier
n. Ro-Ro Cargo Ship
g. Crude Oil Tanker
o. Livestock Carrier
h. Chemical Tanker
p. Vehicle Carrier
q. Barge

2. Year of manufacture:

3. Length of the ship in metres:

4. Dead weight tonnage:

5. Average days stopped in a typical port call:

6. Average days stopped annually:

7. Number of crew members and annual cost: crew, euro/dollar/pound

8. Average speed on voyage in knots:

9. Number of similar ships in your fleet:

10. Average number of voyages per year:

11. Average OPEX ship per year (without fuel consumption): 
12. Average fuel consumption and cost:

tons,

euro/dollar/pound.

13. Average CAPEX ship per year:

14. List of countries where the ship operates: 


\section{Part 2: Cost of anti-fouling measures}

1. What is the frequency that you carry out hull cleaning?

2. What is the cost of removing the ship for cleaning?

3. What is the cost of hull cleaning?

4. What kind of anti-fouling paint do you use?

5. What is the cost of painting?

6. What is the frequency of in water cleaning?

7. What is the cost of in water cleaning?

8. These costs are specified in dollars, euros, pounds or other?

9. Do you use other measures? Please, specify with costs.
1)
2)
3)
4)
5)
6)
7)

Annually, approximately what percentage of overall operational costs is attributable to antifouling measures? 


\section{Part 3: Cost of ballast water measures}

1. What is your ballast water total capacity in $\mathrm{m}^{3}$ ?

2. How many ballast water exchanges (IMO D-1) are done per year on average?

3. What is your ballast water pumping capacity in $\mathrm{m}^{3} /$ hour

4. Does your ship currently meet the IMO D-2 discharge standard?

5. Do you have plans for adapting your ship to meet the US or IMO ballast water regulations?

6. What kind (make, model \& type) of ballast water treatment system (BWTS) do you have?

7. What are/were the installation costs of your BWTS?

1) Cost of installation?

2) Cost of having the ship out of action?

3) Capital cost of purchasing the system?

4) Interest on loans to buy the system?

5) Other costs related to buying and fitting a BWTS?

8. What are the operation costs of the BWTS?
1) Annual maintenance?
2) Fuel consumption (cost per $\left.\mathrm{m}^{3}\right)$ ?
3) Consumables (cost per $\left.\mathrm{m}^{3}\right)$ ?
4) Crew training?
5) Cost of insurance of the system?
6) Other?

9. These costs are specified in dollars, euros, pounds or other?

Annually, approximately what percentage of overall operational costs is attributable to ballast water measures? 


\section{Part 4: Further comments:}

This space is provided for any comments related to this survey that you might consider relevant. 